\title{
SOME ECONOMIC FUNDAMENTALS FOR AN ANALYSIS OF BANKRUPTCY*†
}

\author{
J. FRED WeSton**
}

I

\section{NONCORPORATE BANKRUPTCY}

The central propositions that Dean Meckling sets forth fit into a logical framework: ${ }^{1}$ Increasing the limitations on bankruptcy by eliminating misrepresentation as a bar to discharge or by eliminating or controlling reaffirmation will make bankruptcy more attractive to borrowers. Bankruptcy losses will increase. In the effort to avoid such losses lenders will increase expenses on investigation and monitoring. Since the supply curve of credit is perfectly elastic, the full costs of increased investigation and monitoring, increased bankruptcy loss, and increased nonpayment loss will all be shifted to borrowers and prospective borrowers. The net effect of relaxed bankruptcy laws will therefore be increased borrowing costs. As a consequence, wealth will be transferred to bankrupts from those who repay their loans and from those who are denied loans in regular credit markets.

This is a rigorous, coherent, and valuable formulation. Its full application, however, depends at a number of places on empirical verification. I should therefore like to review this valuable framework and indicate where some qualifications and empirical evidence may be required.

I find some of Dean Meckling's views inconsistent. On the one hand, he questions reforms in bankruptcy law that would transfer wealth to bankrupts from other borrowers; ${ }^{2}$ on the other hand, he does not question the institution of bankruptcy itself, though it causes the wealth transfers he opposes in bankruptcy reforms. For existing limitations on the right to contract Dean Meckling makes optimistic empirical assumptions: "Those kinds of limitations probably raise the cost of lending a little and may force some borrowers into

\footnotetext{
* A commentary on Meckling, Financial Markets, Default, and Bankruptcy: The Role of the State, Law \& Contemp. Prob., Autumn 1977, at 13. This paper was originally delivered, in a slightly different form, at the Liberty Fund, Inc., Seminar on the Economics of Bankruptcy at the Law and Economics Center of the University of Miami School of Law (March 31-April 2, 1977).-Ed.

$\dagger$ I benefited from comments by Professors Harry DeAngelo, Richard Smith, Richard Roll, and Clement Krouse on earlier drafts of this paper.

** Professor, Graduate School of Management, University of California at Los Angeles.

1. See Meckling, Financial Markets, Default, and Bankruptcy: The Role of the State, LAw \& Contemp. Prob. Autumn 1977, at 13, 13-27.

2. See, e.g., id. at 27.
} 
extralegal markets, but the overall effect is probably negligible."3 But for proposed limitations his assumptions are pessimistic. ${ }^{4}$

If this interpretation of Dean Meckling's views is correct, one would ask him why existing bankruptcy legislation is not questioned on the same grounds as its proposed reforms. A more generous interpretation of Meckling's views would be that he does not oppose all wealth transfers to bankrupts from other borrowers but only those not offset by larger benefits. This interpretation merely says that we cannot relax bankruptcy rules indefinitely on the assumption that borrowers as a group will be helped: at some point they may be penalized.

If the latter interpretation of Dean Meckling's views is correct, he is then open to challenge on the specific balance he reaches between bankruptcy costs and benefits. Indefinite relaxation of bankruptcy rules may be more harmful to borrowers than helpful; but how does Dean Meckling choose the right point at which to stop?

As I shall subsequently explain, there are social benefits from the credit system. The costs of credit analysis and monitoring are not necessarily deadweight costs. To the extent that they contribute to an effective system of $\mathrm{fi}$ nancial intermediation, it is possible that further relaxation of bankruptcy laws would provide greater net social benefits.

\section{A. Who Bears the Increased Costs of Lending?}

I would like to raise some questions about the empirical applicability of Dean Meckling's theoretical framework. First, I question his argument that the supply of funds available for credit to individuals, individual proprietors, and partners is perfectly elastic. ${ }^{5}$ This argument is useful for Dean Meckling's purposes: if the supply of credit is perfectly elastic and easing the bankruptcy laws increases cost to lenders, then the full increase in costs will be borne by borrowers or potential borrowers.

But Dean Meckling provides neither theory nor evidence to support the proposition that the supply of funds for noncorporate credit is perfectly elastic. He may be confusing the supply function of the firm with the supply function of the market. Individual firms may be operating in the horizontal sections of their supply functions. This outcome is suggested by the existence of firms of unequal size operating at similar profitability rates. Given the cost of funds to individual intermediary firms, their supply curve is flat. This could also result from a firm's increasing in size until the initial economies of size are exhausted and reaching the area where economies of scale are about balanced by the diseconomies of coordinating large-scale enterprise. There is

\footnotetext{
3. Id. at 29 .

4. Id. at $26-27$.

5. Id. at 19-21
} 
no reason in theory why individual firms might not be operating on the horizontal portions of their supply curves.

But market supply curves are characteristically expected to be positively sloped. The underlying logic for this is the unequal levels of the cost functions of individual firms. Thus at higher prevailing market prices a larger level of capacity enters the market; at lower prevailing market prices some higher cost firms leave the industry. Another reason for positively sloped industry supply functions is that there is competition among industries for inputs (in this case, lendable funds). To attract resources from other uses the industry must pay the opportunity cost. The more resources that must be competed away, in general, the higher will be the opportunity cost.

A positive supply function in the credit market does not alter Dean Meckling's essential position vis-à-vis Mr. Shuchman. ${ }^{6}$ However, it does affect the all-or-nothing nature of Meckling's conclusions. To illustrate this a quick review of basic tax incidence theory is useful. ${ }^{7}$

The issue is the incidence of increased costs to lenders. The increased cost to lenders is similar to an excise tax, and hence tax incidence theory is relevant. The standard framework for tax incidence analysis is a set of demand and supply relationships as depicted in figure I. In the usual discussion it is assumed that a sales or excise tax is levied on the product whose supply and demand functions are represented. The supply curve then shifts upward from $S S$ to $S^{\prime} S^{\prime}$, since the tax adds the same amount to the price at every point on the curve. In figure I the tax imposed is $\$ 4$. The equilibrium price before the tax was $\$ 9$, at which 15,000 units were sold. After the imposition of the tax the new equilibrium is at the intersection of the original demand curve and the new supply curve $S^{\prime} S^{\prime}$. The new equilibrium price is $\$ 11$, at which 12,000 units are sold. Thus, of the $\$ 4$ tax $\$ 2$ is shifted forward to consumers and $\$ 2$ is shifted backward to producers.

Figure I demonstrates that it is not valid to generalize that a sales or excise tax is always shifted forward. Under the demand and supply conditions shown in figure I, the tax is shifted equally. The extent of forward and backward shifting under the partial equilibrium analysis used in figure I depends upon the relative elasticities of the demand and supply curves.

Figure II depicts a situation in which the demand curve is relatively inelastic while the supply conditions are approximately the same as in figure I. A tax of the same amount $(\$ 4)$ is imposed. The new equilibrium price is $\$ 12.30$, and 14,000 units are sold. The price to consumers has increased by $\$ 3.30$ : more than three-fourths of the tax is shifted forward. Thus the more inelastic

6. Shuchman, Theory and Reality in Bankruptcy: The Spherical Chicken, LAw \& Contemp. ProB., Autumn 1977, at 66 .

7. See generally R. Musgrave \& P. Musgrave, Public Finance in Theory and Practice (1973). 
Figure I

Partial Equilibrium Analysis of Tax Incidence

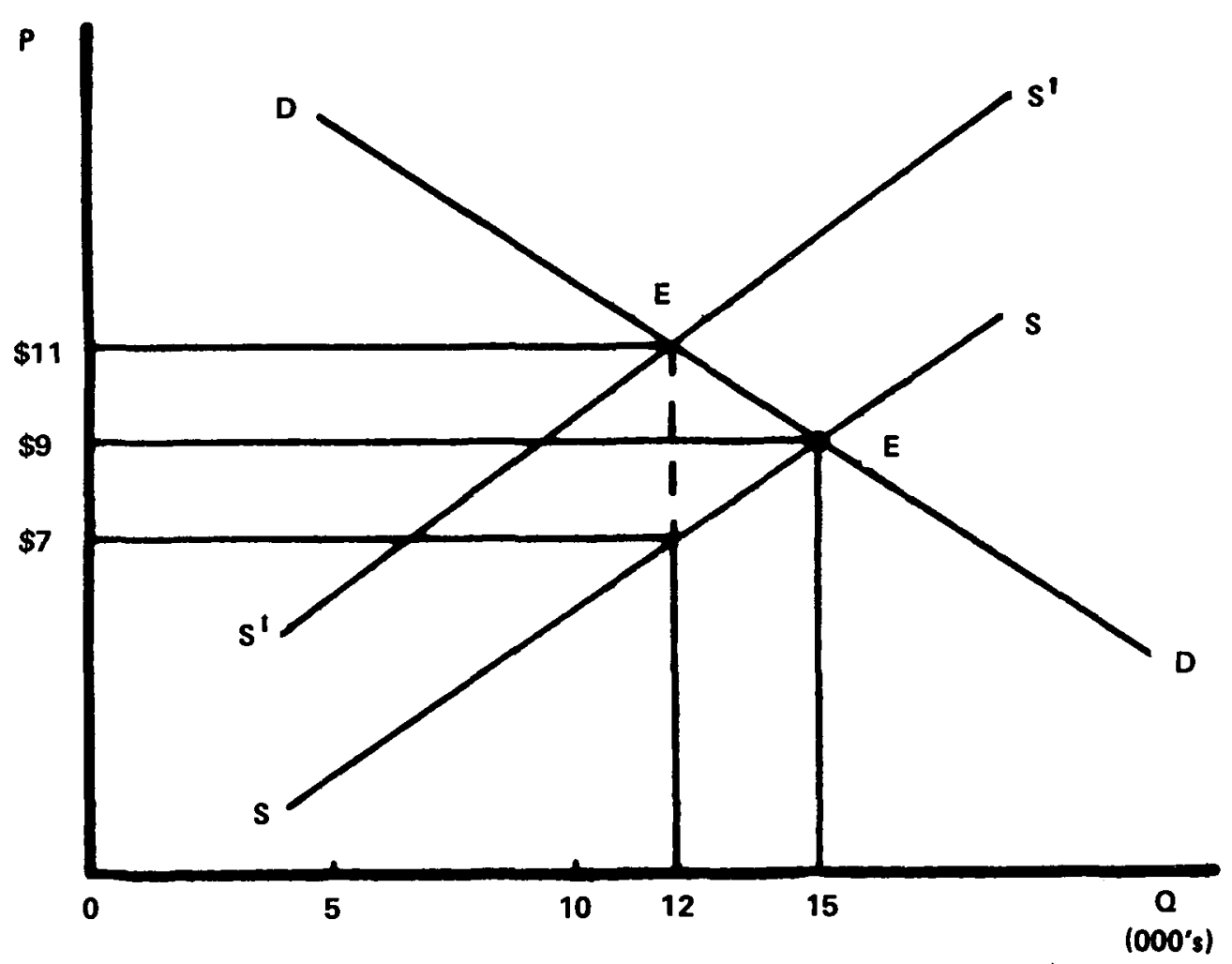

the demand curve, the greater the proportion of a sales or excise tax that will be shifted forward. Conversely, if the demand curve were more elastic, less of the tax would be shifted forward. As the demand curve approaches horizontal, none of the tax will be shifted forward.

Figure III illustrates the influence of the elasticity of the supply curve. In figure III the supply curve is relatively inelastic. Again, a $\$ 4$ tax is imposed. At the new equilibrium the price has increased by $\$ 1$. Thus consumers bear $\$ 1$ of the tax while producers bear $\$ 3$ of the tax. Hence the more inelastic the supply curve, the greater the proportion of the tax that will be borne by producers. In the extreme case in which the supply curve becomes vertical (i.e., becomes completely inelastic), virtually all of the tax is borne by producers. Conversely, if the supply curve were highly elastic, approaching the horizontal, very little of the tax would be borne by producers and virtually all of the tax would be shifted forward to consumers.

Figures I to III are convenient graphic presentations of standard micro- 


\section{Figure II}

Tax Incidence, Inelastic Demand

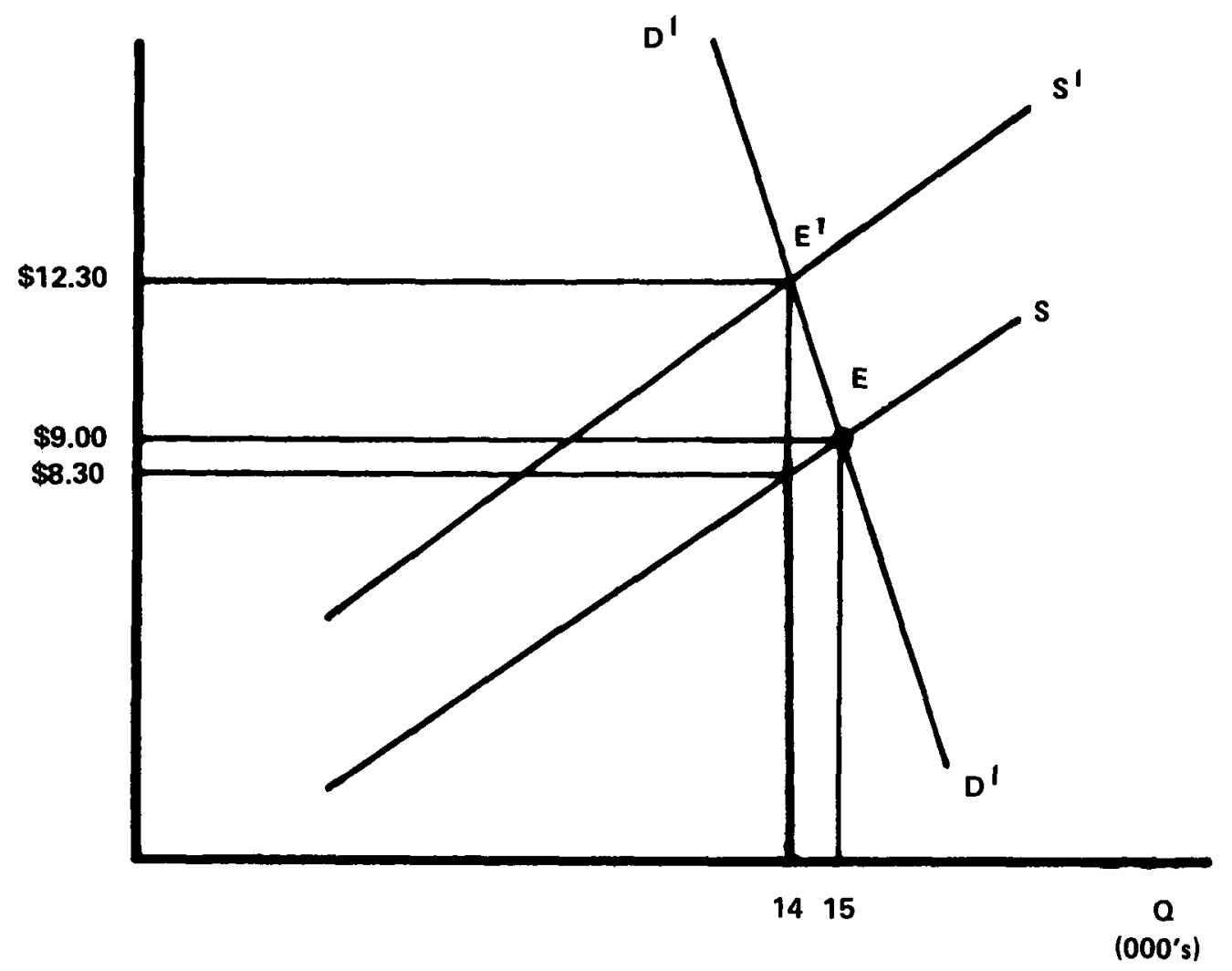

economic analysis of tax incidence. These illustrations are sufficient to demonstrate that the extent to which a sales or excise tax is shifted forward or backward depends upon the relative elasticities of demand and supply curves. Thus if the supply function of credit is positively sloped, the full incidence of increased costs to lenders is not borne by borrowers.

\section{B. Can Lenders Identify Probable Bankrupts?}

A second general proposition set forth by Meckling is that wealth is transfered to bankrupts from borrowers who receive credit and from potential borrowers who are denied credit. ${ }^{8}$ I think this proposition requires more detailed analysis as well. Let me begin by considering polar cases among the

8. Meckling, supra note 1 , at 23. 
Figure III

Tax Incidence, Inelastic Supply

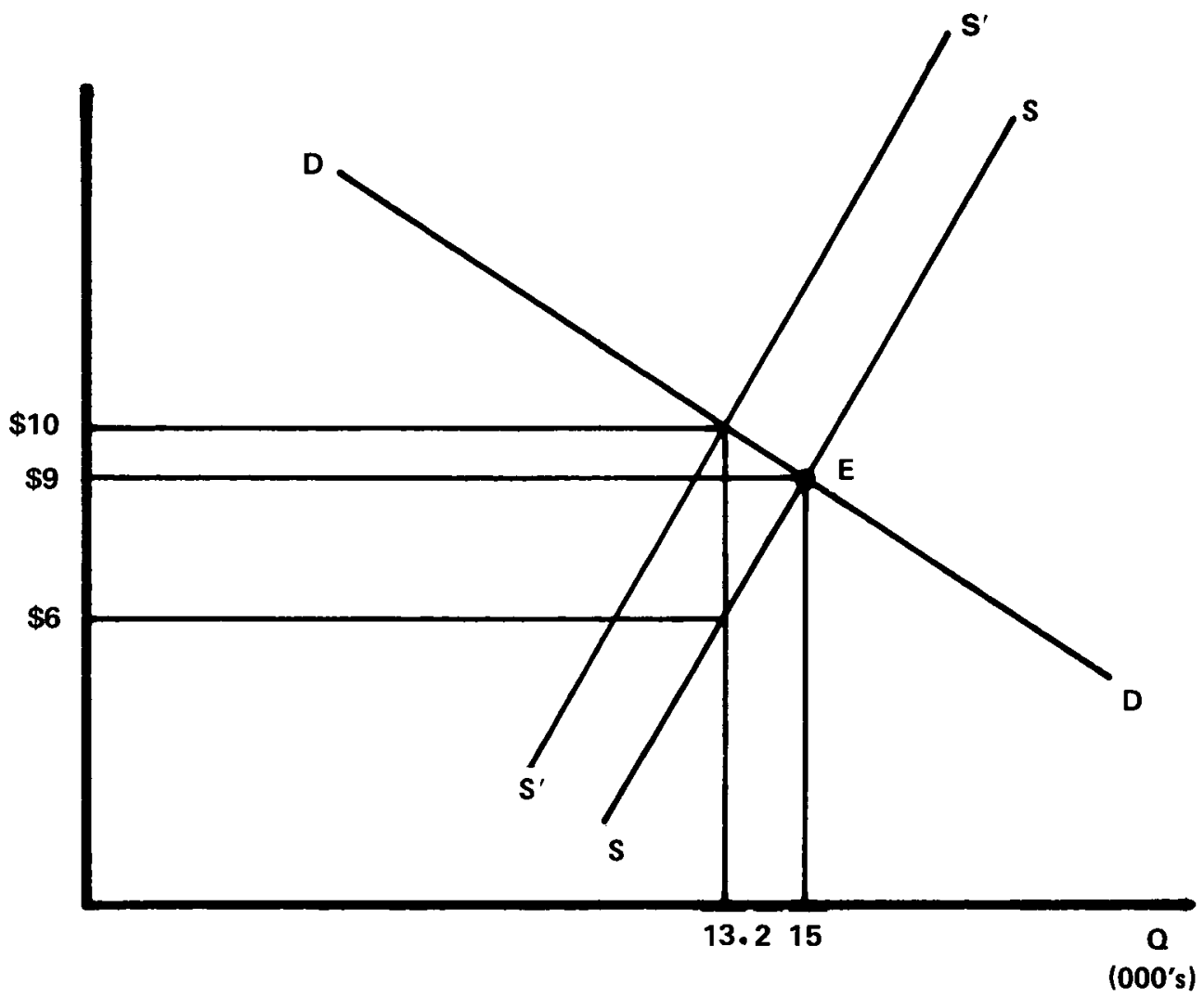

empirical possibilities. At one extreme, if lenders were unable to detect who would go bankrupt, all borrowers would be treated the same. The latter situation is illustrated in figure IV, where the initial supply function $S$ is positively sloped. An easing in the bankruptcy laws would increase bankruptcy losses and probably the costs of credit investigations and loan monitoring as well. The supply function would therefore shift to $S^{\prime}$. But if bankruptcy laws were eased, the quality of the credit offered for sale would change, and the attractiveness of consumer credit would increase. Thus the demand curve would shift to the right: at a given price a larger quantity of credit would be demanded. ${ }^{9}$ An equilibrium might be reached at an increased quantity of credit sold at a higher price. This is consistent with Meckling's basic propositions with only some modification.

9. It may be argued that prices are lowered along a given demand curve. This would lend even stronger support to my conclusions. 


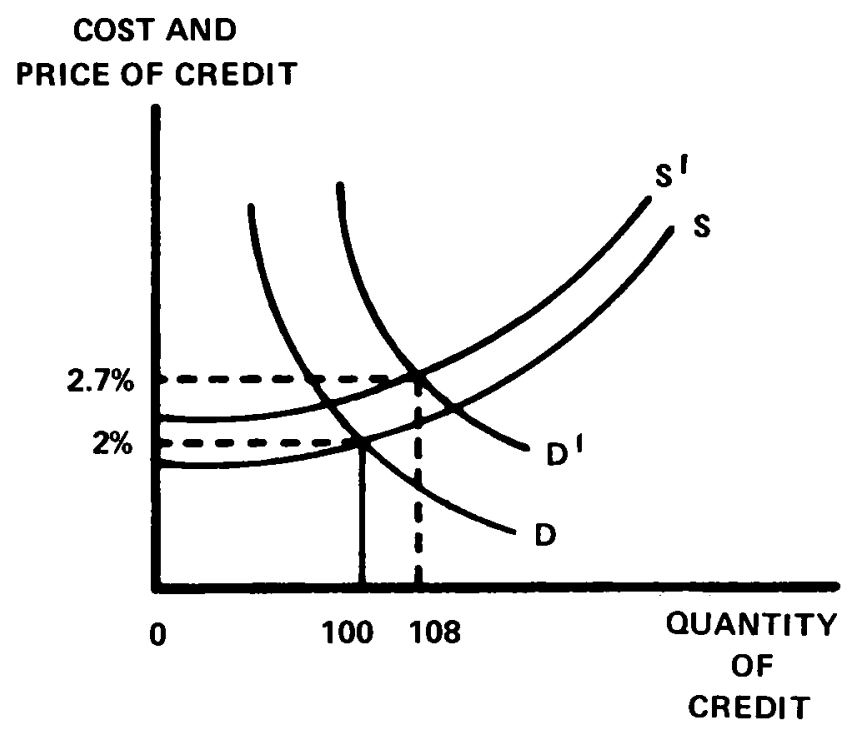

Figure IV

The other extreme possibility is that lenders are able to identify perfectly the probability of bankruptcy. Prices would then reflect the amount of probable loss. This is illustrated by figure $\mathrm{V}$ in terms of two sets of potential borrowers: those who probably will not go bankrupt and those who probably will. The nonbankrupts are depicted in part A of figure V. Since part A contains by hypothesis no bankrupts, a change in the bankruptcy laws would not affect the cost of the loans depicted; thus only one supply curve appears. Part B depicts the bankrupts. Their initial demand function is relatively inelastic because their alternatives to the use of credit are limited. The supply function starts above the equilibrium price for the nonbankrupts in part A. If bankruptcy conditions were eased, losses to lenders would increase, and the supply function would rise to $S_{2}^{\prime}$. Since the easing of bankruptcy laws may be regarded as a change in the quality of credit, the demand curve would shift to the right. At the new equilibrium the quantity of credit extended would be reduced and the price would be higher. In other words, the price would be higher to those who received credit, and some potential borrowers would not receive credit.

In this second extreme case there would be smaller wealth transfer effects. The situation for the nonbankrupts depicted in part $\mathrm{A}$ of figure $\mathrm{V}$ would be unchanged by legal reform. The bankrupts in part B of figure $V$ would bear the costs in the higher price of credit to the bankrupts who receive credit and in the denial of credit to the potential bankrupts who would now be out of the market. 


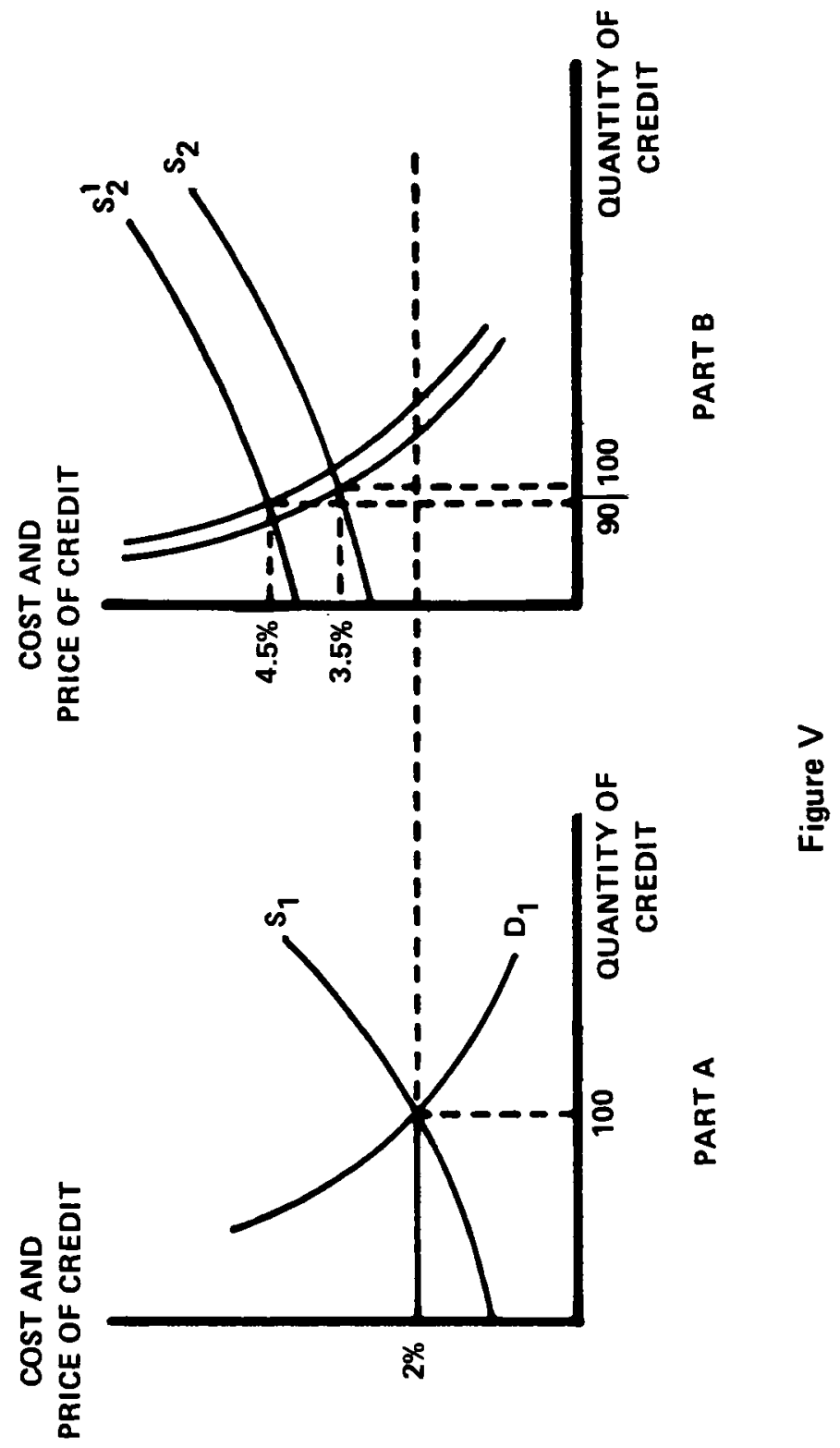

The thrust of Dean Meckling's presentation is that reality lies somewhere between the polar cases I have presented. Perhaps it does. But this requires empirical verification. In addition, there is a more basic empirical consideration: where current reality lies in the range between net positive economic gains from bankruptcy and bankruptcy laws that are too easy and unduly in- 
crease lenders' costs. For this analysis we need to review the basics of the economic functions of the credit system. ${ }^{10}$

\section{The Economic Functions of the Credit System}

Financial assets or securities are created for a number of reasons. As Dean Meckling points out, economic agents have different attitudes toward desired present and future rates of consumption and present and future holdings of wealth. ${ }^{11}$ One of the consequences of their different views of the future is that the savings of various economic agents may differ from their investments in real assets.

Savings are defined as current income less current expenditures. Agents have a savings surplus if their savings exceed their investments in real assets: they hold financial assets. Agents have a savings deficit if their current savings are less than their investment in real assets: they have financial liabilities.

The economic rationale for financial markets can thus be readily established. In an economy with either barter or money but no financial claims, savings could accumulate only in money balances. These money balances would necessarily equal investment for each economic agent. As a consequence, economic agents without real investment opportunities would accumulate money balances that would be idle. Economic agents with many investment opportunities would lack sufficient money balances to use their investment opportunities. Without financial claims the investments made by some economic agents would necessarily be inferior to the investments that could be made by others if they were enabled to use their investment opportunities more fully.

Thus, the rationale for the institution of financial claims is to improve the allocation of real resources and thereby increase real returns on real wealth. A financial claim issued by an agent incurring a savings deficit by receiving another agent's savings surplus is called a primary security. Primary securities can be transformed by a financial intermediary into indirect securities when the intermediary substitutes its liabilities for the liabilities of others and its financial claims for the financial claims of others. ${ }^{12}$

The institution of financial intermediaries improves the efficiency of $f_{1}$ -

10. See generally J. C. Van Horne, The Function and Analysis of Capital Market Rates (1970).

11. Meckling, supra note 1 , at 14 .

12. Credit extended by sellers is properly included in the category of financial intermediation.

A minor quibble may be made with Dean Meckling's characterization of financial intermediaries. Meckling states, "[A]ll of the funds that are borrowed must in the end come from individuals; that is, individuals or institutions acting as agents for individuals must be induced to hold voluntarily the claims which debtors offer in exchange for funds." $I d$. at 19 . In a fractionalreserve commercial banking system a substantial portion of the funds is created by the expansion of the system on a monetary base supplied by the central bank. While Meckling's categorical statement is therefore inaccurate, it is not crucial to his arguments. 
nancial markets in three ways. First, financial intermediaries provide more diverse and flexible products and thereby provide greater convenience. To facilitate purchases by economic agents seeking to make investments in excess of their current savings, the financial intermediary can combine driblets of savings. Or it can divide a large pool of savings. One borrower can use the funds of many savers, or one saver may have funds that can be made available to many borrowers. Financial intermediaries provide lenders and borrowers with indirect securities with characteristics and terms tailored to their needs and desires.

Second, a financial intermediary can provide greater opportunities for liquidity and diversification, thereby reducing risk. Through purchases of different primary securities with different characteristics less than perfectly correlated with one another, the dispersion of the returns from secondary securities is reduced. By recombining and rearranging the maturities of financial claims and managing its own cash flows, the financial intermediary can also provide the liquidity and the time pattern of maturities desired by both borrowers and lenders.

Third, financial intermediaries can achieve economies of scale by spreading various types of outlays for specialized fixed assets and by developing expertise over a large volume of transactions. Both primary and secondary securities involve contracts around which complex legal rules and regulations have developed. A large investment in expertise is thus required for transactions in these securities. Financial intermediaries spread this investment over many identical transactions. The repetitive characteristics of financial transactions also facilitate various types of automation in record keeping.

Thus, by creating a more convenient product, by increasing opportunities for diversification and liquidity, and through the economies of specialization and large-scale operation, financial intermediaries improve the allocation of real resources and thereby increase real returns.

The theory of financial intermediation summarized above suggests that the economic advantages of credit exceed its cost. Thus the two- or three-percent cost of credit does not represent a dead-weight loss. The economic justification for financial intermediation argues that the two- or three-percent cost of consumer credit is more than made up in improved allocation of economic resources, and increases in the size and growth of the economy.

If this is true for the existing levels of cost, it may be equally true for an increment in costs resulting from a relaxation of the bankruptcy laws for the benefit of debtors. Hence, whether relaxation of the bankruptcy laws imposes net costs on the economy or achieves net gains depends upon where the cost-benefit balance stands at present; that is, on the gains from the quantity and price of financial intermediation in the economy at present compared with what the gains would be under eased bankruptcy laws that would increase both the quantity and price of financial intermediation. 
Let me attempt some estimates of where the cost-benefit ratio of consumer credit stands. These are only rough approximations to provide some questions for further in-depth research.

D. Implications of the Improved Technology of Credit Administration

With the revolution in computer technology there has been a similar revolution in the technology of compiling, storing, and retrieving credit information. Computer data banks are readily developed with information on both individuals and businesses. This facilitates the supply of credit information and has led to sophisticated techniques of credit scoring and discriminant analysis for predicting nonpayment. ${ }^{13}$

It is reasonable to infer therefore that the costs of compiling credit information have been reduced in recent years. The change may be visualized as depicted in figure VI. With the improvement in the technology of credit information and credit monitoring, the supply curve of credit has shifted from $S$ to $S n$. As a consequence, the quantity of credit supplied has changed from 100 costing 3 percent interest to 120 costing 1.8 percent. If the treatment of bankruptcy were liberalized, then as Professor Meckling suggests, ${ }^{14}$ costs might rise to $S^{\prime}$. I postulate that demand for credit services would also in-

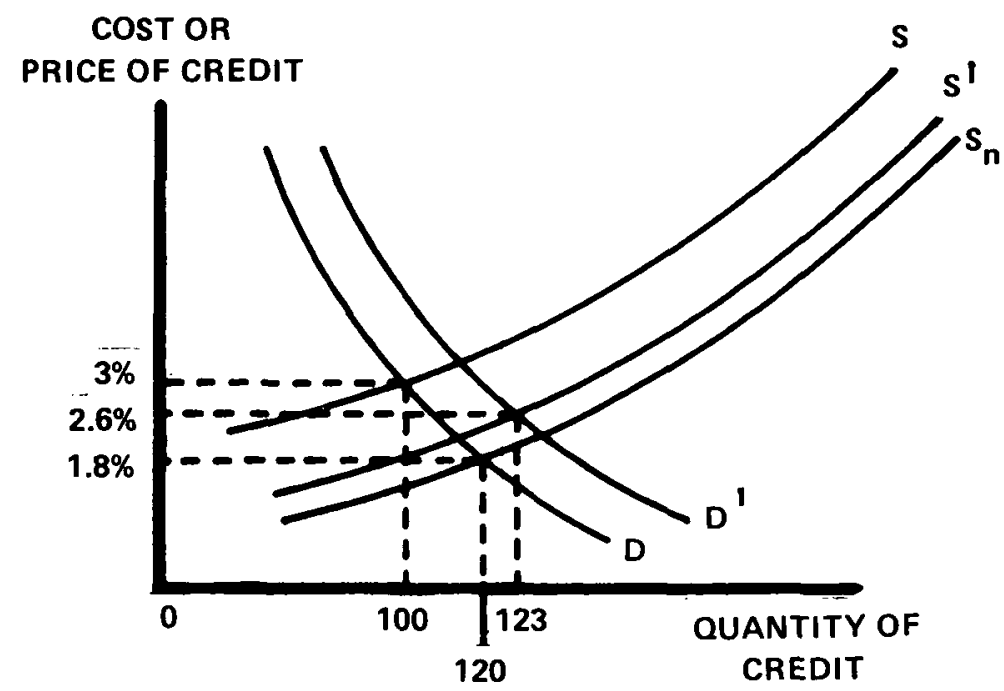

Figure VI

13. See, e.g., Altman \& Eisenbeis, Financial Applications of Discriminant Analysis: A Clarification (1976) (Salomon Bros. Center for the Study of Financial Institutions, New York University, working paper no. 79); R. Eisenbeis \& R. Avery, Discriminant Analysis and Classification Procedures: Theory and Applications (1976).

14. Meckling, supra note 1 , at 24-27. 
crease because of the liberalized treatment of bankrupts. The new equilibrium might therefore be reached at a larger quantity and a lower cost than the original equilibrium. Thus, the new equilibrium might be at a quantity of 123 at a cost of 2.6 percent.

Some data may be cited in support of the analysis set forth above. Baddebt loss ratios for business firms generally run quite low, well under one-half of one percent. ${ }^{15}$ Debts discharged in bankruptcy are also relatively small. For example, Stanley and Girth state, "Some $\$ 2$ billion of debts were discharged in the bankruptcy courts in 1968-about 0.2 percent of the private debt outstanding." 16 This represents a loss ratio of well under one-half of one percent. It could well be argued that given the functions performed by the credit system and financial intermediation, the loss ratios are quite low in relation to the economic gains. Hence, an argument can be made that credit extension could be expanded and loss ratios increased with net economic benefits.

Other evidence may be cited to suggest that risks borne by lenders have been relatively low. If the risks borne by lenders were onerous, new forms of lending would be developed to reduce them. For example, leasing, which gives lenders a superior position because they continue to own the asset leased, would have grown even more if less favorable forms of direct lending imposed undue burdens on lenders. Yet it appears that the main factor in the growth of leasing has been tax considerations rather than the risk of lenders. ${ }^{17}$

In this context the distinction made by Dean Meckling between wealth transfers and social costs, ${ }^{18}$ though insightful and valuable, can be extended. He says that when a debtor defaults, a wealth transfer takes place, but there is no social cost. When a firm uses resources to conduct credit checks or to monitor loans, real social costs are incurred. Similarly, the services of attorneys, judges, and others in the bankruptcy system are said to be resources that could have been put to other uses. Dean Meckling then predicts that if the treatment of debtors in bankruptcy is relaxed, firms extending credit will allocate more resources to credit checks and loan monitoring. ${ }^{19} \mathrm{He}$ concludes that these resources represent social costs and that the full incidence of the increased costs is on borrowers. But to the extent that the outlays for credit checks and loan monitoring facilitate an effective credit system, there may be net social benefits from these outlays. To observe that social costs are incurred

15. See L. Troy, Almanac of Business and Industrial Financial Ratios (1975).

16. D. T. Stanley, M. Girth, V. Countryman, G. Jantscher, W. Law, V. Rosenblum, \& M. Shimm, Bankruptcy: Problems, Process, Reform 40 (1971) [hereinafter cited as Stanley \& GIRTH].

17. See Vanderwicken, The Powerful Logic of the Leasing Boom, Fortune, Nov. 1973, at 132, 136.

18. Meckling, supra note 1 , at 22 n.22.

19. Id. at 23. 
in the production of credit may be no more meaningful than observing that social costs are incurred in the production of bread.

\section{E. Implications of the Bankruptcy Process for Social Costs}

The foregoing analysis suggests still other kinds of interactions that were set aside in the presentation of Dean Meckling. He comments at the beginning of his paper: ${ }^{20}$

... [The bankruptcy] system is a very sophisticated and complex institution.

Much of the controversy over revising it has revolved about the judicial procedures and administration of the bankruptcy system. These are not subjects on which economists have a comparative advantage, and I shall for the most part behave accordingly.

There is much wisdom in Dean Meckling's observation, and so it is with some trepidation that I venture to raise questions about the economic implications of the institutional structure, procedures, and administration of the bankruptcy system. Clearly, one purpose of the bankruptcy process is to certify the change in contractual obligations that insolvency necessitates. But more important from an economic standpoint, the legal process seeks to scrutinize the obligations, position, and prospects of the bankrupt to ascertain whether he in fact needs a bankruptcy discharge. Fundamentally, this amounts to reducing the moral hazard that unscrupulous borrowers will beat the credit system by declaring bankruptcy when it is not fully justified. This is similar to the physical examination in life insurance, which seeks to screen out those who wish to buy life insurance because of a physical condition that has increased their risks of untimely death or disability.

If the bankruptcy process in fact meets a need for protection against moral hazard, the amount of credit available through the financial system and financial intermediation will be greater than it would have been without bankruptcy. Given the interaction of financial intermediation with the real economy, this contributes to allocative efficiency and growth.

But it seems to me that the moral hazard is much smaller in credit than in areas such as life, health, or fire insurance. My review of the evidence in this area leads to the judgment that there is a considerable overproduction of legal services in the bankruptcy process. Here I would agree with the observation of the Brookings study that bankruptcy represents more ${ }^{21}$

problems of guidance and management. The major need is for speedy, discriminating, understanding processing of about two hundred thousand small, largely uncontested cases each year. This is an administrative function rather than a judicial function, and it should be performed by a staff selected on a

20. Id. at 13 .

21. D. T. Stanley \& M. GikTh, supra note 16, at 200. 
merit basis and aided by the most modern records management and data processing methods.

Furthermore, I would argue that those who extend credit do not need the elaborate protection of the bankruptcy process, for the following reasons:

1. The revolution in the technology of credit information permits better screening of applicants.

2. It is now much easier to obtain information on the amount of credit that a borrower has already obtained and the alternative sources of credit that he has used.

3. Unlike life, health, or fire insurance, credit is not a one-shot transaction in which large amounts are involved.

4. The user of credit usually anticipates needing more credit in the future, and hence feels pressure to establish a good record and reputation.

5. Since the borrower has to borrow repeatedly, there are repeated experiences from which the lender can learn about him.

6. Lenders can control their exposure through the credit standards that they use. Credit standards can be set for levels of income, duration or continuity of income, previous payment record, etc.

7. Since lending involves a large number of relatively independent occurrences, lenders can benefit from the law of large numbers. Even without elaborate credit checking and loan monitoring, lenders can develop experience with the characteristics of borrowers and predictable loss ratios. Lenders can thus limit their loss exposure or take probabilities of loss into account in estimating their costs.

These seven aspects of credit cast doubt on Dean Meckling's assumption that lenders need protection from the moral hazard of unjustified bankruptcy. In his analysis of default in ideal credit markets, Meckling observes that "[c]ontract provisions will increase the probability of repayment if they will impose costs on the borrower if he defaults." ${ }^{22}$ This leads Meckling to the conclusion that "[i]f restrictions are placed on the extent to which [the borrower] can agree to impose costs on himself in case of default, the borrowernot the lender-will be forced to bear higher loan costs." 23

It seems to me that this analysis is premised on an assumption of moral hazard that ignores the repetitive nature of borrowing. This assumption is expressed by Dean Meckling as follows: "[Debtors] will repay only if default is on balance less attractive than repayment." 24 I would argue that the alternatives available to debtors are not so simple. Their need to borrow from a number of sources, their knowledge that credit information is collected by lenders, their need for future loans, all provide strong stimuli to debtors to

22. Meckling, supra note 1 , at 16 .

23. Id.

24. Id. 
honor their obligations. The nature of contractual provisions is perhaps of reduced significance, because of the borrowers' need to enter similar contracts repeatedly. This gives considerable control to lenders that they would not have in a one-shot transaction.

Furthermore, lenders need not be concerned with the behavior of individual borrowers. With knowledge of the nature of credit arrangements generally, lenders can predict loss ratios for their entire portfolios. Because of the repetitiveness of recontracting, the terms of individual contracts are relevant mainly as a basis for predicting what total loss ratios will be for a given set of credit standards. Lenders can exercise control in the type of credit standards they use and in the extent to which loss ratios will be reflected in their cost functions. These, in turn, will affect the equilibrium prices for credit or goods.

Thus, there is not a great need for judicial review of the bankruptcy process to reduce moral hazard or protect lenders. Without the costs of this process financial intermediation could take place with reduced social costs to the economic system as a whole. ${ }^{25}$

\section{II}

\section{Corporate BankRuptcy}

Dean Meckling says that "[a] parallel between corporate and noncorporate bankruptcy is worth noting." ${ }^{26}$ However, two differences of major conceptual importance may greatly affect analysis of corporate bankruptcy. One, an investor can take a position in all classes of the securities of a corporation, that is, all forms of equity and debt claims; but an investor cannot take a position in the human capital of noncorporate borrowers. Two, bankruptcy costs are a relatively small percentage of corporate assets but a relatively large percentage of the assets of noncorporate bankrupts. ${ }^{27}$

As a result of the second difference, the amount or proportion of borrowing by corporate entities is no longer a critical variable. As a result of the first difference, corporate investment can be equivalent to investing in an unlevered firm. Because of the opportunity to invest in different classes of se-

25. Another possible economic effect may be noted: Suppose that attempts to collect bad debts are expensive and the net returns are small. One possible reason would be that there are diseconomies of scale in bad-debt collection. Under these conditions it would be advantageous for lenders to reduce efforts to collect bad debts and raise the price of credit to compensate. But this would require concerted behavior, because competition prevents one lender from raising prices if others do not.

If government made bankruptcy laws so lenient as to render attempts at collection futile, efforts to collect on bad debts would be reduced. Hence, the effect of the easing of bankruptcy laws may be to enable all lenders to reduce bad-debt collection and raise prices. Thus, government intervention may produce an effect that otherwise could only be produced by collusion.

26. Meckling, supra note 1 , at 33 .

27. Dreyfuss, Greenwood, \& Fiorello, The Impact of Proposed Changes in Bankruptcy Administration 38 , in Institute for the Future, Report of the Commission on the Bankruptcy Laws of the UNITED STATES, part III (1973). 
curities, investors can avoid the need for credit analysis and monitoring. This shows the importance of mergers and other methods with a minimum of procedural complications and costs as alternatives to liquidation. Alternatives such as mergers maintain the organization values of a corporation. ${ }^{28}$

These differences between corporate and noncorporate bankruptcy pose the fundamental question, on what body of theory are we drawing in formulating propositions about corporate bankruptcy? Standard microeconomic theory has little to say. For example, among leading textbooks neither Samuelson's Economics ${ }^{29}$ nor Alchian and Allen's University Economics ${ }^{30}$ list the word "bankruptcy" in their indexes. Alchian and Allen discuss entry but do not list exit in their index. Samuelson lists neither entry nor exit. Yet the theory of atomistic competition accords an important role to entry and exit in adjusting long-run supply and demand and allocating resources efficiently. Thus standard microeconomics has little to offer. Legal doctrine has the absolute priority principle, which is relaxed somewhat in chapter XI proceedings. Meckling refers to some pieces of finance theory that provide insights. ${ }^{31}$ But a theory of how firms function, which is critical to the formulation of principles for the evaluation of bankruptcy laws, is not found in any of these.

\section{A. The Firm as an Organization ${ }^{32}$}

A firm is an organization, or team. As any team, it requires practice and experience before reaching its full effectiveness, and practice and experience take time. A theory of bankruptcy must take into account the time it takes a corporate team to reach their full effectiveness and the uncertainty during that time about how effective they will ultimately be.

When a firm fails in some sense, it is not only legal contracts or competing financial claims that must be readjusted: the firm itself must readjust. Somehow it has failed to adapt to its environment, that is, to its specific market or the general economy. Sometimes a change in management is the necessary adaptation, and in some bankruptcies that adaptation is made. If the economic environment has changed, the firm's resources may need reorientation. Yet new management, new capital, and a new corporate orientation alter the identity of the organization substantially. The new organization needs time to learn and gain experience before it can reach its full potential. And during that time, its potential will again be uncertain.

This is why valuation of firms in bankruptcy is enormously difficult. It

28. The foregoing point was suggested in discussions with Richard Roll.

29. P. Samuelson, Economics (9th ed. 1973).

30. A. Alchian \& W. Allen, University Economics (2d ed. 1967).

31. Meckling, supra note 1 , at 32-37.

32. The following theory of the firm will be formulated verbally, although a mathematical formulation is also needed. 
indeed would be more convenient, as Dean Meckling observes, ${ }^{\mathbf{3}}$ if bankruptcy were confined to circumstances beyond a firm's control-if a firm's destiny were determined by the spin of a roulette wheel. The bankruptcy system would then be reduced to a croupier who doles out winnings and collects the losses. In reality, however, the fate of a firm is not an easily calculable gamble but a wide range of possibilities that depend on the future state of the firm's environment and the ultimate adaptability of the organization.

\section{B. Valuation of an Organization}

Thus, the value of a firm can only be estimated through an assignment of probability to each possible future environment and an estimation of the organization's ability to adapt in each case. This degree of uncertainty casts doubts on Meckling's statements about valuation, for example: ${ }^{\mathbf{3 4}}$

It is difficult to reconcile the proposition that a firm is bankrupt with the proposition that stockholders have some positive equity. . . If the firm has a present value which exceeds the sum of the claims held by creditors, it should always be able to meet its current cash-flow requirements simply by substituting new loans for old.

This argument would be compelling if the present value of a firm were certain. In that case, the status of a firm could be determined by the simple comparison Dean Meckling suggests. What happens in reality is that a firm's future outlook-estimated by the compound probabilities we have listedchanges to such an extent that the firm's contractual obligations must be altered as well. The need for such a contractual readjustment is perceived long before Dean Meckling's simple calculation is possible.

Dean Meckling's comments on reorganization ignore this uncertainty in similar fashion. For firms in reorganization he proposes, "Why not use the market to determine the value of the firm?" 35 Yet while the rehabilitation of such a firm is in progress, the market (or anyone else) lacks a clear view not only of the future values of the firm under various states of its environment but also of those possible future states as they affect the particular firm. Thus claimants will have to bear a high degree of uncertainty before they know the future state of the firm's environment, the future value of the firm in that environment, and the value of their claims on the firm.

I agree with Dean Meckling that the SEC staff should not be the source for these predictions. ${ }^{36}$ Nothing in the activities of the SEC gives it an advantage in estimating a firm's value. Such estimates depend on an analysis of the economic outlook for the firm's industry and the prerequisites for success in that industry, an analysis in which, among government agencies, the Depart-

33. Meckling, supra note 1 , at 30 .

34. Id. at $32-33$.

35. Id. at 38 .

36. Id. 
ment of Commerce has an advantage. However, the government seems an unpromising source of authoritative or influential valuations that require business judgments in which the greatest advantage lies outside of government. The government's only responsibility is to see that ultimately viable businesses do not fail because of temporary disturbances in the economic environment. This requires government maintenance of economic stability or government assistance to viable businesses threatened by adverse conditions.

\section{Recommendations for Corporate Bankruptcy}

In the perspective of these observations, I would reformulate Meckling's criteria for a corporate bankruptcy system. Dean Meckling says, "[T]he optimal corporate bankruptcy system must fulfill two requirements: (1) it must generate the optimal number of bankruptcies, and (2) it must do so at minimum cost." ${ }^{37}$ First, the cost criterion can be elaborated as follows: Analysis of business bankruptcies indicates that they tend to occur in lines of businesses to which entry is easy and periodically brings excess capacity. ${ }^{38}$ Where entry is easy, ease of exit is also desirable to improve the flow of resources in the economy. The least costly form of bankruptcy in this sense will be the form that speeds the flow of excess capacity back into more productive use. Thus the criterion of minimum cost will require a streamlined bankruptcy process.

Yet criteria for a corporate bankruptcy system must be more profound and more concrete. Additional criteria should include (1) maximum incentives for cost efficiencies in industry, (2) the lowest cost of capital from both debt and equity sources that is consistent with efficient capital markets, and (3) an absence of incentives or opportunities for one class of claimants to benefit at the expense of another.

In light of these criteria and our observations on the nature of the firm, some specific recommendations can be made.

\section{A Modified Absolute Priority Rule}

Dean Meckling quotes the work of Jerold Warner on the subversion of the absolute priority rule in chapter XI proceedings. ${ }^{39}$ In Warner's example senior bondholders receive claims of $\$ 10$ million and junior bondholders receive claims of $\$ 5$ million on a firm whose estimated value is $\$ 15$ million. Warner shows that if the actual market value of the firm is only $\$ 12$ million, the senior bondholders' claims of $\$ 10$ million, or two-thirds of the

37. Id. at 31 .

38. See Dickerson \& Kawaja, The Failure Rates of Business, in The Financing of Small Business: A Current Assessment (I. Pfeffer ed. 1967); Weston, The Position of Small Business in the American Economy, in id.

39. Warner, Bankruptcy, Absolute Priority, and the Pricing of Risky Debt Claims, 4 J. Financial Econ. 239, 244 (1977), quoted in Meckling, supra note 1, at 35. 
firm's estimated value, will be worth only $\$ 8$ million.

Yet this will depend on the nature of the claims given to each group. If the senior bondholders were given creditors' claims and the junior bondholders were given a portion of the stockholders' claims, the senior claims could still be worth $\$ 10$ million of the actual $\$ 12$ million market value, and the junior claims could be worth only the residual $\$ 2$ million.

This illustration indicates how the absolute priority doctrine might be relaxed to account for the uncertainty of valuation. Absolute priority could be given to assigned senior claims, and all other claimants given the status of stockholders - that is, a share only in the residual value of the firm. This modification of the priority rule would accommodate the uncertainty of a firm's true value without harming the senior claimants. I believe that this system of state-contingent claims is the only solution to the valuation problem.

\section{Mergers as a Substitute for Corporate Bankruptcy}

The cost criterion for a bankruptcy system-and the elaboration of that criterion above-lead to a consideration of mergers as an alternative to bankruptcy. Mergers are one of the mechanisms in the capital market for the reallocation of resources to uses in which their value is rehabilitated or conserved. ${ }^{40}$ Mergers can thus replace bankruptcy as a mechanism to ease the exit of excess capacity from an industry. The possibility of a merger also increases the range of prospective buyers for a firm whose outlook has changed. This would greatly clarify the valuation of these firms.

Yet if my theory of the firm is correct, legal doctrines of merger should be reconsidered. At present mergers can be defended from antitrust litigation by a showing that one of the firms is failing: efforts to prevent a merger-created monopoly are futile if one of the firms will drop from the competition in any case ${ }^{41}$ However, this defense fails if the court determines that the firm can be rehabilitated by a change in management.

As we have seen, such a determination can hardly be certain. It requires an estimation of the new management's chance of success under each possible future state of the economy and a further estimation of probability for each of those states. Furthermore, the value of mergers as substitutes for bankruptcy makes an expansion of the failing-firm defense desirable. The present doctrine foils this defense as long as the firm can be saved; yet creditors and shareholders of a floundering firm need help before the firm is beyond salvation. By permitting mergers of firms that are floundering but not yet failing, the courts could greatly improve the reallocation of resources that would otherwise be reallocated in bankruptcy.

40. See Manne, Mergers and the Market for Corporate Control, 73 J. Political Econ. 110-120 (1965).

41. See Low, The Failing Company Doctrine Revisited, 38 Fordham L. Rev. 23 (1969). 